\title{
Prevalence and trend of hepatitis $C$ virus infection among blood donors in Chinese mainland: a systematic review and meta-analysis
}

Xiaofei Gao ${ }^{1,2+}$, Qian Cui ${ }^{1 \dagger}$, Xiang Shi ${ }^{1,2+}$, Jing Su${ }^{1}$, Zhihang Peng ${ }^{1}$, Xin Chen ${ }^{1}$, Na Lei ${ }^{1}$, Keqin Ding ${ }^{1}$, Lu Wang ${ }^{3}$, Rongbin $\mathrm{Yu}^{1 *}$ and Ning Wang ${ }^{3^{*}}$

\begin{abstract}
Background: Blood transfusion is one of the most common transmission pathways of hepatitis C virus (HCV). This paper aims to provide a comprehensive and reliable tabulation of available data on the epidemiological characteristics and risk factors for HCV infection among blood donors in Chinese mainland, so as to help make prevention strategies and guide further research.
\end{abstract}

Methods: A systematic review was constructed based on the computerized literature database. Infection rates and 95\% confidence intervals (95\% Cl) were calculated using the approximate normal distribution model. Odds ratios and $95 \% \mathrm{Cl}$ were calculated by fixed or random effects models. Data manipulation and statistical analyses were performed using STATA 10.0 and ArcGIS 9.3 was used for map construction.

Results: Two hundred and sixty-five studies met our inclusion criteria. The pooled prevalence of HCV infection among blood donors in Chinese mainland was 8.68\% (95\% Cl: 8.01\%-9.39\%), and the epidemic was severer in North and Central China, especially in Henan and Hebei. While a significant lower rate was found in Yunnan. Notably, before 1998 the pooled prevalence of HCV infection was 12.87\% (95\%Cl: 11.25\%-14.56\%) among blood donors, but decreased to 1.71\% (95\%Cl: 1.43\%-1.99\%) after 1998. No significant difference was found in HCV infection rates between male and female blood donors, or among different blood type donors. The prevalence of HCV infection was found to increase with age. During 1994-1995, the prevalence rate reached the highest with a percentage of $15.78 \%$ (95\% Cl: 12.21\%-19.75\%), and showed a decreasing trend in the following years. A significant difference was found among groups with different blood donation types, Plasma donors had a relatively higher prevalence than whole blood donors of HCV infection (33.95\% vs 7.9\%).

Conclusions: The prevalence of HCV infection has rapidly decreased since 1998 and kept a low level in recent years, but some provinces showed relatively higher prevalence than the general population. It is urgent to make efficient measures to prevent HCV secondary transmission and control chronic progress, and the key to reduce the HCV incidence among blood donors is to encourage true voluntary blood donors, strictly implement blood donation law, and avoid cross-infection.

Keywords: hepatitis C virus infection, blood donors, meta-analysis

\footnotetext{
* Correspondence: rongbinyu@njmu.edu.cn; wangnbj@163.com

+ Contributed equally

'Department of Epidemiology and Biostatistics, School of Public Health, Nanjing Medical University, Nanjing 210029, PR China

${ }^{3}$ Department of Epidemiology, National Center for AIDS/STD Control and

Prevention, Chinese Center for Disease Control and Prevention, Beijing

100050, PR China

Full list of author information is available at the end of the article
} 


\section{Background}

Chronic infection with hepatitis $\mathrm{C}$ virus ( $\mathrm{HCV}$ ) is a major and growing public health problem, which could easily lead to chronic liver disease, cirrhosis and even hepatocellular carcinoma [1]. The prevention and control of HCV infection showed complexity and challenge in describing geographic distribution of HCV infection, determining its associated risk factors, and evaluating cofactors that accelerate hepatitis $\mathrm{C}$ progression. Estimated 170 million persons are infected with $\mathrm{HCV}$ worldwide and more than 3.5 million new sufferers occurred annually [2]. According to the national epidemiological survey of viral hepatitis from 1992 to 1995 , average anti-HCV positive rate was $3.2 \%$ in the general Chinese population, amounting to more than 30 million infected individuals [3].

The rapid global spread of $\mathrm{HCV}$ is believed to have occurred primarily because of efficient transmission through blood transfusion and parenteral exposures with contaminated equipment [4]. Blood donors, particularly those that rely on blood donation as a source of income, had a very high prevalence of HCV infection [5]. Recent studies have reported that the current residual risk of transfusion-transmitted $\mathrm{HCV}$ infection in China is about 1 in 40,000-60,000 donations, higher than that found in more developed countries [6]. With the implemention of blood donation law in 1998, many blood centers relied on other methods to motivate donors, mostly through employer-organized blood collection, but these donors may not have been true volunteers, as they may be coerced by the employer to some extent. In recent years, the true voluntary donors are gradually becoming the main source of blood donation in many blood centers in China [7]. Among paid blood donors, the HCV prevalence has reached $5.7 \%$ or higher [8]. However, among employer-organized donors and volunteer donors, the $\mathrm{HCV}$ prevalence was reported at lower level between 1.1$2.3 \%$, and $0.46 \%$, respectively $[7,9]$.

A large amount of studies have been done in the last decade on $\mathrm{HCV}$ infection and its associated risk factors among blood donors. However, many of them drew incompatible or even contradictory conclusion and the utilization of these statistics are therefore limited. This paper reviews on the available studies so as to provide comprehensive and reliable epidemiological characteristics of HCV infection among blood donors in China, which is speculated to help make prevention strategies and guide further research.

\section{Methods}

\section{Literature search}

Literatures on the HCV prevalence among blood donors in China were acquired through searching PubMed, Embase, China National Knowledge Infrastructure
(CNKI), and Wanfang Database from 1990 to 2010. In order to search and include related studies as many as possible, we used combinations of various key words, including hepatitis $\mathrm{C}$ virus or $\mathrm{HCV}$, blood donors, and China or Chinese Mainland.

\section{Selection and data abstraction}

All the potentially relevant papers were reviewed independently by two investigators through assessing the eligibility of each article and abstracting data with standardized data-abstraction forms. Disagreements were resolved through discussion. The following information, though some studies did not contain all of them, were extracted from the literatures: first author's name, publication date, study period, province of sample, blood donor recruitment methods (paid blood donors, employer-organized donors, or true volunteer donors), type of blood donation (categorized as plasma donors and whole blood donors), sampling size, the number of subjects infected with HCV, HBV, and HIV or coinfected with two or three of these viruses, gender, age (18-30 years and 31-60 years), and blood type, etc.

The inclusion criteria were: (1) studies in the mentioned four databases with full text, despite the language of original text; (2) studies reporting anti-HCV positive rates among blood donors in Chinese Mainland; (3) studies using anti-HCV as a detection index of HCV. The exclusion criteria were: (1) studies without specific sample origins; (2) studies with overlapping time intervals of sample collection from the same origin; (3) studies with a sample size less than 50; (4) studies that failed to present data clearly enough or with obviously paradoxical data.

\section{Statistical analysis}

In our review, random effect models were used for meta-analysis, considering the possibility of significant heterogeneity between studies which was tested with the $\mathrm{Q}$ test $(P<0.10$ was considered indicative of statistically significant heterogeneity) and the $I^{2}$ statistic (values of $25 \%, 50 \%$ and $75 \%$ are considered to represent low, medium and high heterogeneity respectively). FreemanTukey arcsin transform to stabilize variances, and after the meta-analysis, investigators can transform the summary estimate and the CI boundaries back to proportions using sin function, the specific conversion details can be seen in reference [10]. Stratified analyses were performed by study locations, gender, age, study period, blood donor recruitment methods, type of blood donation, and blood type. The $\mathrm{Z}$ or $\chi^{2}$ test was used to assess the differences among the subgroups. Data manipulation and statistical analyses were undertaken using the Statistical Software Package (STATA) 10.0 (STATA Corporation, College Station, TX, USA, 2009), and ArcGIS 9.3 
(ESRI, Redlands, California, USA) was used for map construction.

\section{Results}

According to the literature search strategies, 726 studies (90 studies in PubMed, 636 studies in CNKI and Wanfang database) were identified, but 461 studies were excluded based on the inclusion and exclusion criteria (Figure 1). There were 11 studies in English [8,9,11-19] and 254 studies in Chinese [20-273] of the finally adopted 265 studies.

\section{General information of samples}

A total of 4519313 blood donors between the ages of 18 to 60 were included, with a wide range of blood donation frequency from 1 to more than 50 times. Some donors had a duration (the period from the first blood donation to when selected in original research) longer than 15 years. The majority of blood donors were men, approximately $57.72 \%$ (101319/175540), while women accounted for $42.28 \%$ (74221/175540). The occupation of blood donors was widely distributed. Voluntary blood donors mainly came from college students, health care providers, officials, and military from Chinese People's Liberation Army (PLA), while paid blood donors were mostly from peasants, low-wage workers, and unemployed individuals.

The blood samples mainly came from blood banks, hospitals, and Centers for Disease Control and Prevention (CDC). The studies of our review involved in the following regions of 29 provinces and cities: Central China (Hunan, Hubei, Henan), North China (Beijing,

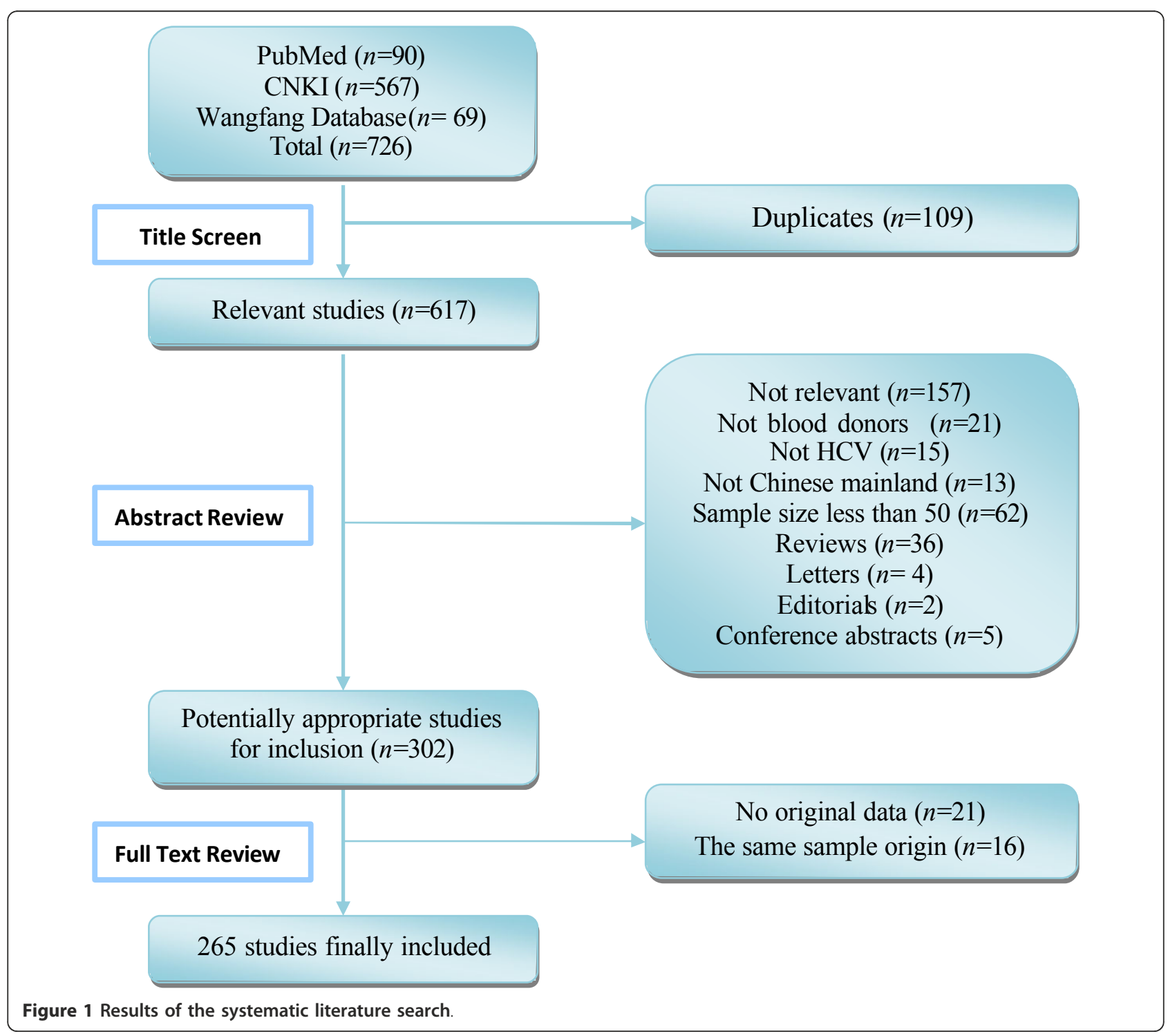


Hebei, Shanxi, Tianjin, Inner Mongolia), South China (Guangdong, Guangxi), Northwest China(Shanxi, Gansu, Ningxia, Qinghai, Xinjiang), Northeast China (Liaoning, Jilin, Heilongjiang), Southwest China (Yunnan, Guizhou, Sichuan, Chongqing), East China (Shandong, Jiangsu, Anhui, Zhejiang, Fujian, Shanghai, Jiangxi).

\section{Prevalence of HCV infection among blood donors in Chinese mainland \\ Region}

As seen in Table 1 and Figure 2, 3, the pooled prevalence of $\mathrm{HCV}$ infection among blood donors in Chinese mainland from 1990 to 2010 was 8.68\% (95\% CI: 8.01\%9.39\%). Dramatic geographic difference in pooled HCV infection rates among blood donors was observed. The epidemic was severest in North and Central China, where the HCV infection rate were $13.45 \%$ (95\%CI: $11.41 \%$ $15.67 \%$ ) and $14.74 \%$ (95\%CI: $11.06 \%-18.80 \%)$, respectively. The lowest prevalence was in South China with the rate of $2.88 \%$ (95\% CI: $2.19 \%-3.64 \%)$. Before 1998, the pooled prevalence of HCV infection was $12.87 \%$ (95\% CI: $11.25 \%$ $14.56 \%$ ) among blood donors, with the highest rates found in Henan (35.04\%, 95\% CI: 23.62\%-47.41\%), then Hebei (29.26\%, 95\% CI: 19.63\%-39.98\%), and then the pooled

Table 1 Prevalence of HCV infection among blood donors at different regions

\begin{tabular}{|c|c|c|c|c|c|c|c|}
\hline \multirow{2}{*}{$\begin{array}{c}\text { Study } \\
\text { location }\end{array}$} & \multirow{2}{*}{$\begin{array}{l}\text { Province } \\
\text { of study }\end{array}$} & \multicolumn{2}{|r|}{ Total $^{\mathbf{b}}$} & \multicolumn{2}{|c|}{ Before 1998} & \multicolumn{2}{|c|}{ After 1998} \\
\hline & & No & $\begin{array}{c}\text { Prevalence \% } \\
(95 \% \mathrm{Cl})\end{array}$ & No & $\begin{array}{c}\text { Prevalence \% } \\
(95 \% \mathrm{Cl})\end{array}$ & No & $\begin{array}{l}\text { Prevalence \% } \\
(95 \% \mathrm{Cl})\end{array}$ \\
\hline \multirow{7}{*}{$\begin{array}{l}\text { East } \\
\text { China }\end{array}$} & Anhui & 21 & $11.25(6.56,17.04)$ & 19 & $12.91(8.31,18.34)$ & 2 & $0.90(0.01,3.14)$ \\
\hline & Fujian & 4 & $3.38(2.19,4.83)$ & 4 & $3.38(2.19,4.83)$ & & \\
\hline & Jiangsu & 21 & $11.41(6.12,18.07)$ & 13 & $14.84(8.73,22.23)$ & 7 & $3.83(0.75,9.13)$ \\
\hline & Jiangxi & 6 & $5.65(1.52,12.21)$ & 4 & $5.15(2.31,9.07)$ & 1 & $0.38(0.26,0.52)$ \\
\hline & Shandong & 27 & $6.34(5.00,7.80)$ & 17 & $8.37(5.84,11.31)$ & 7 & $1.64(1.26,2.07)$ \\
\hline & Shanghai & 4 & $2.59(0.38,6.66)$ & 4 & $2.59(0.38,6.66)$ & & \\
\hline & Zhejiang & 12 & $2.02(1.06,3.28)$ & 8 & $3.08(1.40,5.42)$ & 4 & $0.79(0.30,1.51)$ \\
\hline \multirow{5}{*}{$\begin{array}{l}\text { North } \\
\text { China }\end{array}$} & Beijing & 9 & $2.95(1.78,4.41)$ & 7 & $3.53(1.84,5.74)$ & & \\
\hline & Hebei & 19 & $26.92(15.20,40.57)$ & 18 & $29.26(19.63,39.98)$ & 1 & $0.41(0.39,0.43)$ \\
\hline & Shanxi & 9 & $14.63(8.73,21.74)$ & 5 & $24.17(18.14,30.77)$ & 2 & $0.41(0.06,2.31)$ \\
\hline & Tianjin & 5 & $2.35(0.98,4.33)$ & 2 & $1.97(0.32,5.02)$ & 2 & \\
\hline & $\mathrm{IM}^{\mathrm{a}}$ & 4 & $9.36(3.00,18.76)$ & 4 & $9.36(3.00,18.76)$ & & \\
\hline \multirow{2}{*}{$\begin{array}{l}\text { South } \\
\text { China }\end{array}$} & Guangdong & 13 & $1.05(0.65,1.54)$ & 5 & $1.41(0.87,2.07)$ & 8 & $0.91(0.49,1.47)$ \\
\hline & Guangxi & 8 & $9.75(6.94,12.98)$ & 5 & $17.49(1.71,44.67)$ & 2 & $3.31(0.08,10.90)$ \\
\hline \multirow{3}{*}{$\begin{array}{l}\text { Central } \\
\text { China }\end{array}$} & Hubei & 11 & $10.81(5.51,17.61)$ & 8 & $13.04(6.41,21.61)$ & 3 & $5.54(0.63,14.84)$ \\
\hline & Hunan & 13 & $8.01(3.22,14.70)$ & 8 & $17.11(9.81,25.95)$ & 3 & $0.55(0.35,0.81)$ \\
\hline & Henan & 26 & $20.63(12.98,29.53)$ & 16 & $35.04(23.62,47.41)$ & 9 & $3.83(1.75,6.66)$ \\
\hline \multirow[t]{5}{*}{ Northwest } & Shanxi & 6 & $11.25(4.81,19.91)$ & 4 & $17.42(3.60,38.61)$ & 1 & $1.99(1.95,2.03)$ \\
\hline & Ningxia & 2 & $0.69(0.10,1.78)$ & 1 & $1.18(1.03,1.35)$ & 1 & $0.32(0.29,0.37)$ \\
\hline & Qinghai & 3 & $2.60(0.10,8.34)$ & 2 & $3.59(0.00,13.69)$ & 1 & $1.10(0.511 .91)$ \\
\hline & Gansu & 6 & $2.60(5.44,17.49)$ & 3 & $23.32(3.62,53.16)$ & 2 & $0.83(0.29,1.64)$ \\
\hline & Xinjiang & 5 & $14.52(3.01,32.54)$ & 4 & $19.67(3.79,43.83)$ & 1 & $1.45(1.31,1.58)$ \\
\hline \multirow[t]{4}{*}{ Southwest } & Sichuan & 10 & $11.31(3.19,23.49)$ & 8 & $15.60(7.61,25.77)$ & 2 & $0.71(0.28,1.34)$ \\
\hline & Yunnan & 1 & $0.23(0.17,0.29)$ & & & 1 & $0.23(0.17,0.29)$ \\
\hline & Guizhou & 9 & $5.00(1.76,9.78)$ & 6 & $6.91(2.88,12.51)$ & 3 & $1.71(0.43,3.81)$ \\
\hline & Chongqing & 5 & $1.33(0.50,2.54)$ & 2 & $2.22(0.19,6.36)$ & 3 & $0.97(0.18,2.37)$ \\
\hline \multirow[t]{4}{*}{ Northeast } & Liaoning & 6 & $5.84(3.87,8.18)$ & 5 & $5.00(3.29,7.06)$ & 1 & $11.82(8.29,15.89)$ \\
\hline & Heilongjiang & 4 & $4.06(2.86,5.47)$ & 4 & $4.06(2.86,5.47)$ & & \\
\hline & Jilin & 5 & $5.38(2.26,9.69)$ & 3 & $7.19(1.08,18.03)$ & 2 & $3.59(0.17,16.81)$ \\
\hline & Pooled & 268 & $8.68(8.01,9.39)$ & 189 & $12.87(11.25,14.56)$ & 69 & $1.71(1.43,1.99)$ \\
\hline
\end{tabular}

a. IM: Inner Mongolia.

b. When calculating the pooled prevalence rate either before or after 1998 respectively, the studies that spanned 1998 were excluded. In that case, number of total literatures is bigger than the sum of literature number before 1998 and after 1998. 


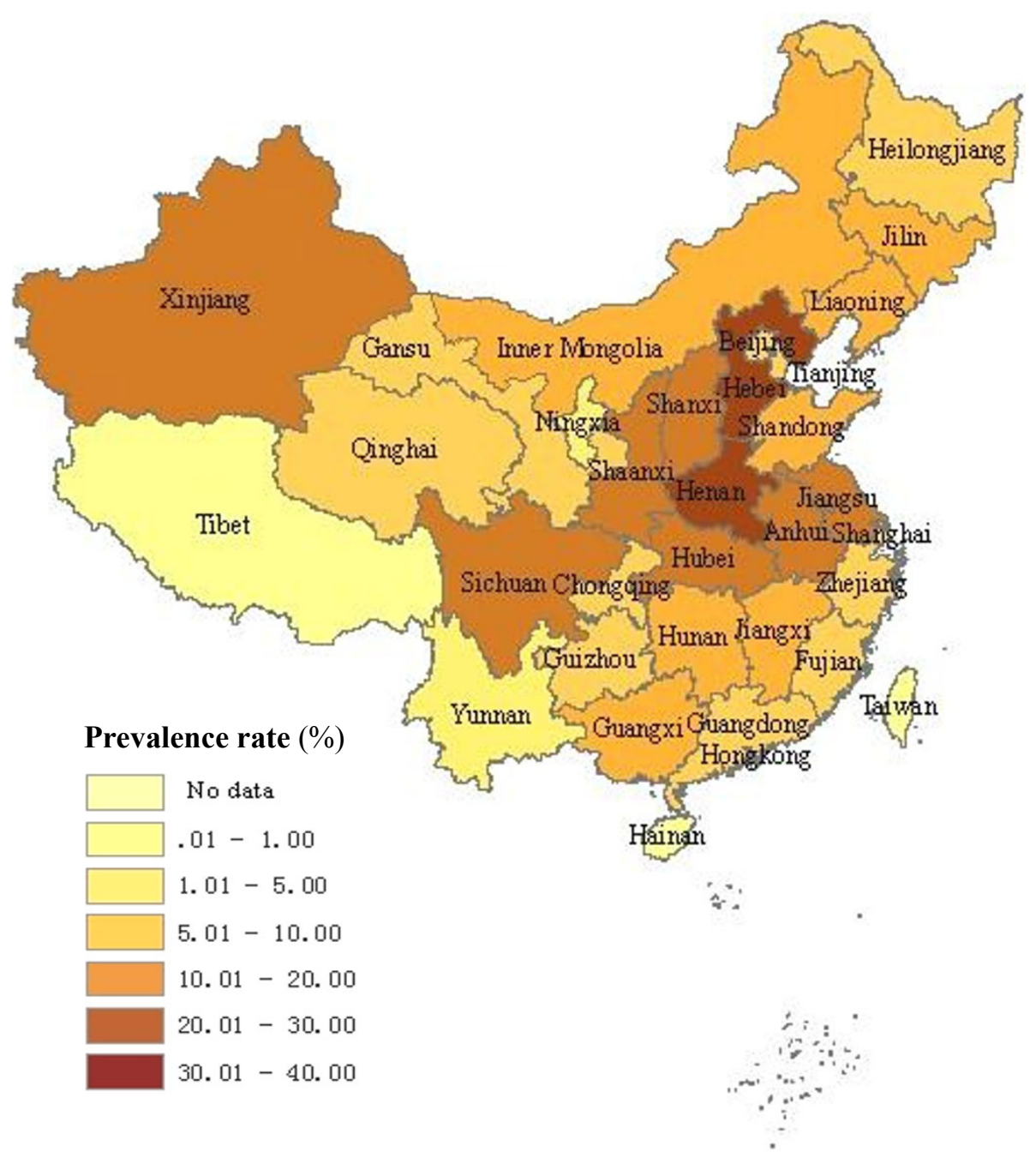

Figure 2 The regional distribution of pooled prevalence of HCV infection among blood donors in China before 1998

prevalence decreased to $1.71 \%$ (95\%CI: $1.43 \%-1.99 \%)$ after 1998.

\section{Gender}

A total of 79 studies have investigated the association between the prevalence rate of HCV infection and gender among blood donors. HCV infection rate of male blood donors was 9.87\% (95\%CI: 8.26\%-11.63\%), while female blood donors had a rate of $9.78 \%$ (95\%CI: $7.88 \%$ $11.89 \%)$. There was no significant statistical difference between males and females $(Z=0.62, P=0.54)$.

Age

There were 30 studies indicating the association between the prevalence rate of $\mathrm{HCV}$ infection and age among blood donors. In most studies blood donors were divided into two groups by the age of 30 years old. HCV infection rate of individuals aged $18-30$ was $4.91 \%$ (95\% CI: 3.89\%-6.05\%), while the prevalence rate of individuals aged $31-60$ was $8.99 \%$ (95\% CI: $6.86 \%-11.37 \%$ ), and there was significant statistical difference between two groups $(\mathrm{Z}=66.02, P<0.01)$.

Time

As presented in Table 2, 179 studies were divided into 9 groups according to the study period, and Figure 4 was drawn on the prevalence of HCV in each group. During 1994-1995, the prevalence rate reached the highest, which was $15.78 \%$ (95\% CI: $12.21 \%-19.75 \%)$. Since 1995 , the rates showed a decreasing trend among blood donors, even as low as 0.36\% (95\% CI: 0.09\%-0.81\%) during 2006-2010.

\section{Blood type}

As displayed in Table 3, among blood type A, B, AB, and $\mathrm{O}$ donors, the $\mathrm{HCV}$ infection rates were $8.18 \%(95 \%$ CI: $4.55 \%-12.77 \%$ ), $7.58 \%$ (95\%CI: $4.26 \%-11.73 \%$ ), $8.15 \%$ (95\%CI: $4.64 \%-12.54 \%$ ), and $7.85 \%$ (95\%CI: $4.64 \%-$ $11.82 \%)$, respectively. There was no significant statistical difference among four blood types $\left(\chi^{2}=4.97, P=0.17\right)$. 


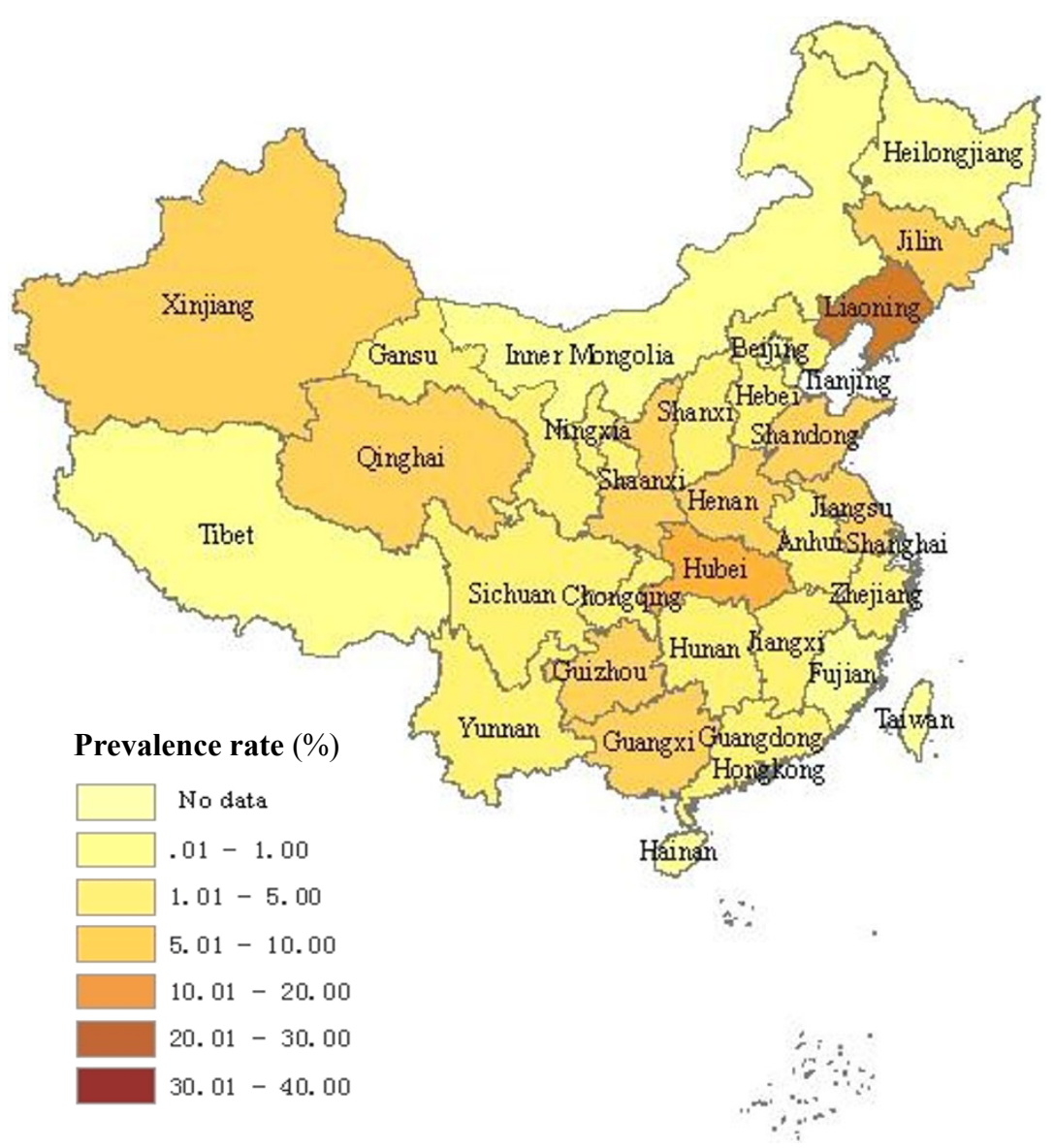

Figure 3 The regional distribution of pooled prevalence of HCV infection among blood donors in China after 1998.

\section{Donation type}

As seen in Table 4, HCV infection rate of voluntary blood donors and paid blood donors were $0.97 \%(95 \%$ CI: $0.79 \%-1.16 \%)$ and $15.53 \%$ (95\% CI: $13.28 \%-17.91 \%)$

Table 2 Prevalence of HCV infection among blood donors at different study period

\begin{tabular}{|c|c|c|c|c|c|}
\hline \multirow{2}{*}{$\begin{array}{l}\text { Study } \\
\text { period }\end{array}$} & \multirow{2}{*}{$\begin{array}{l}\text { No. of } \\
\text { studies }\end{array}$} & \multirow{2}{*}{$\begin{array}{c}\text { Prevalence of } \\
\text { HCV } \\
\%(95 \% \mathrm{Cl})\end{array}$} & \multicolumn{2}{|c|}{ Heterogeneity } & \multirow[t]{2}{*}{ Mode } \\
\hline & & & $1^{2}$ & $\begin{array}{c}P \\
\text { value }\end{array}$ & \\
\hline 1990-1991 & 8 & $13.42(5.79,23.62)$ & $98.90 \%$ & 0.00 & REM \\
\hline 1992-1993 & 48 & $13.66(9.93,17.87)$ & $99.70 \%$ & 0.00 & REM \\
\hline 1994-1995 & 57 & $15.78(12.21,19.75)$ & $99.80 \%$ & 0.00 & REM \\
\hline 1996-1997 & 23 & $7.34(5.40,9.54)$ & $99.30 \%$ & 0.00 & REM \\
\hline 1998-1999 & 13 & $3.97(2.67,5.54)$ & $98.50 \%$ & 0.00 & REM \\
\hline $2000-2001$ & 7 & $4.45(0.48,12.08)$ & $99.90 \%$ & 0.00 & REM \\
\hline $2002-2003$ & 14 & $2.34(1.17,3.87)$ & $99.50 \%$ & 0.00 & REM \\
\hline $2004-2005$ & 4 & $1.65(0.56,3.29)$ & $97.40 \%$ & 0.00 & REM \\
\hline $2006-2010$ & 5 & $0.36(0.09,0.81)$ & $99.30 \%$ & 0.00 & REM \\
\hline
\end{tabular}

REM: random effect model. respectively. There was significant statistical difference ( $\mathrm{Z}=325.65, P<0.01)$. The prevalence of HCV infection differed significantly $(Z=142.22, P<0.01)$ among plasma donors and whole blood donors, which was 7.90\% (95\%CI: $6.44 \%-9.51 \%)$ and $33.95 \%$ (95\% CI: $29.80 \%-38.17 \%)$, respectively.

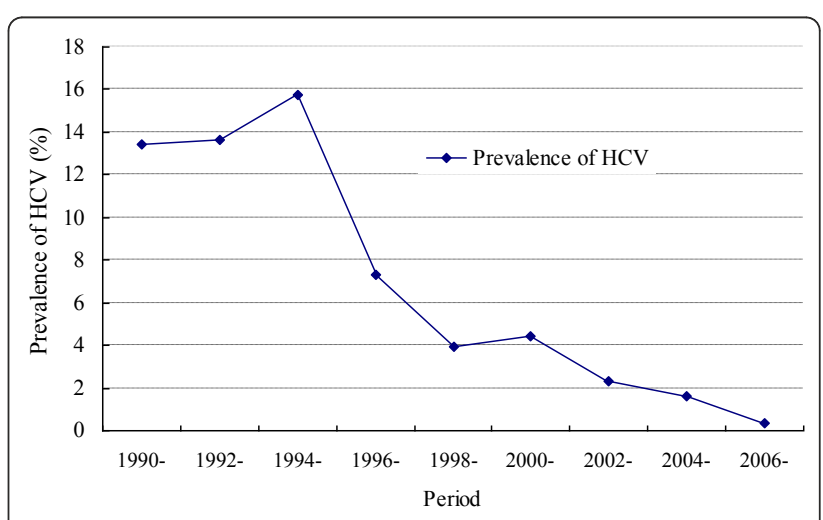

Figure 4 Prevalence of HCV infection among blood donors at different study period. 
Table 3 Prevalence of HCV infection among blood donors of different blood type

\begin{tabular}{|c|c|c|c|c|c|}
\hline \multirow{2}{*}{$\begin{array}{l}\text { Blood } \\
\text { type }\end{array}$} & \multirow{2}{*}{$\begin{array}{l}\text { No. of } \\
\text { studies }\end{array}$} & \multirow{2}{*}{$\begin{array}{c}\text { Prevalence of } \\
\text { HCV } \\
\%(95 \% \mathrm{Cl})\end{array}$} & \multicolumn{2}{|c|}{ Heterogeneity } & \multirow[t]{2}{*}{ Model } \\
\hline & & & $I^{2}$ & $\begin{array}{c}P \\
\text { value }\end{array}$ & \\
\hline A & 14 & $8.18(4.55,12.77)$ & $98.80 \%$ & 0.00 & REM \\
\hline B & 14 & $7.58(4.26,11.73)$ & $98.80 \%$ & 0.00 & REM \\
\hline$A B$ & 14 & $8.15(4.64,12.54)$ & $94.90 \%$ & 0.00 & REM \\
\hline O & 14 & $7.85(4.64,11.82)$ & $98.80 \%$ & 0.00 & REM \\
\hline
\end{tabular}

REM: random effect model.

\section{Discussion}

As a blood-borne pathogen, HCV virus was frequently detected among paid blood donors in China in the early 1990s [9]. To improve the safety of blood supply and reduce the risk of transfusion-transmitted diseases, the Chinese government has outlawed the use of paid blood donors since 1998. As a result, Chinese blood banks now rely on various other methods to recruit blood donors, mostly on employer-organized donors and true voluntary donors [274]. This transition in the blood donor recruitment methods has been associated with a gradual decrease in the prevalence of anti-HCV among donors. In addition, an HCV RNA screening strategy was implemented in 2010 in all Chinese blood banks, which has also contributed to the decline of HCV prevalence rate. This review shows that the pooled prevalence of $\mathrm{HCV}$ infection among blood donors was 8.68\% (95\% CI: $8.01 \%$ to $9.39 \%$ ) from 1990 to 2010 , significantly higher than the estimated $3.2 \%$ in the general population of China [1]. It is noteworthy that before 1998 the pooled prevalence of $\mathrm{HCV}$ infection was $12.87 \%$ among blood donors, but dramatically decreased to $1.71 \%$ after 1998. In economically developed regions, the decreasing trend was more prominent due to effective control measures.

Our results showed significant geographic difference of the prevalence of anti-HCV. Compared with other regions, North and Central China had relatively higher anti-HCV positive rates among blood donors, accounting for $13.45 \%$ and $14.74 \%$. Meanwhile, the lowest epidemic rate was found in South China with a percentage of $2.88 \%$. Notably, during the period through 1990 and 1998, the prevalence rates were commonly at high level among different regions of China. Especially in Henan and Hebei, the rates even reached $35.04 \%$ and $29.26 \%$ respectively. After 1998, the general epidemic rates have rapidly decreased, benefited from the government's prohibition of using paid blood donors. However, the reduction of HCV prevalence was not that obvious in North and Central China. Possible reasons for this lack of reduction may include larger population migration, poor economic conditions, higher HCV infection rates in the general populations, or limited sampling.

According to the national epidemiological survey of viral hepatitis from 1992 to 1995 , HCV infection rate among the general population increased gradually with age, but the prevalence rate had no significant difference between male and female [275], which is consistent with our findings that significant difference was found between two age groups but not between gender. The findings indicated that both male and female had the same susceptibility to HCV infection, while the older had increased chance of being HCV-infected. Since the paid donors were usually driven by economic benefits, the association of age with HCV infection may also be explained by increased exposure chances with a greater number of instances of blood donation times or longer duration of blood donation. It is early for a conclusive explanation until systematic investigations are performed and causal relation underneath is revealed $[35,61,65,153,179]$.

By and large, the prevalence rate of $\mathrm{HCV}$ infection showed a rising trend among blood donors from 1990 to 1995 , but significantly decreased from 1996 to 2010 (Figure 3). Our results revealed an outbreak of $\mathrm{HCV}$ infection in blood donors around 1995. As recalled, lots of plasma collection stations were established in different regions before 1995. However, the majority of them were illegal and severe cross-contamination on plasmapheresis frequently occurred due to those commonly existed nonstandard operations, such as neglecting sterilization, lacking accurate detection method of anti-HCV, improperly usage of non-disposable needles. In some places, the prevalence rate of $\mathrm{HCV}$ was reported as high as $80 \%$ [275]. Given the urgency of the situation, in

Table 4 Prevalence of HCV infection among blood donors of different donation types

\begin{tabular}{|c|c|c|c|c|c|}
\hline \multirow[t]{2}{*}{ Donation type } & \multirow[t]{2}{*}{ No. of studies } & \multirow[t]{2}{*}{ Prevalence of $\mathrm{HCV} \%(95 \% \mathrm{Cl})$} & \multicolumn{2}{|c|}{ Heterogeneity } & \multirow[t]{2}{*}{ Model } \\
\hline & & & $P^{2}$ & $P$ value & \\
\hline voluntary donation & 73 & $0.97(0.79,1.16)$ & $99.60 \%$ & 0.00 & REM \\
\hline paid donation & 89 & $15.53(13.28,17.91)$ & $99.70 \%$ & 0.00 & REM \\
\hline whole blood donors & 53 & $7.90(6.44,9.51)$ & $98.50 \%$ & 0.00 & REM \\
\hline plasma donors & 64 & $33.95(29.80,38.17)$ & $99.40 \%$ & 0.00 & REM \\
\hline
\end{tabular}

REM: random effect model. 
1995 the government implemented strict management on blood stations. Besides, the detection technology of anti-HCV got greatly improved with better sensitivity and specificity in the following years [276]. With the implementation of Blood Donation Law of China in 1998, real voluntary blood donors replaced paid donors and became a steady and major source of the blood supply. All these measures lead to the great achievements in control and prevention of HCV infection. Nowadays reports of $\mathrm{HCV}$ infection among the true voluntary blood donors could rarely been seen in China.

Our study showed that among blood type A, B, AB, and $\mathrm{O}$ donors, the prevalence of $\mathrm{HCV}$ infection were $8.18 \%, 7.58 \%, 8.15 \%$, and $7.85 \%$, respectively. No significant difference was found between blood types and the epidemic rate of $\mathrm{HCV}$, indicating that blood type is not associated with susceptibility to HCV infection. This finding was consistent with the studies of Lu KQ [52], Zhou ZD [119], and Pu SF [269]. While it was a different story in the study of Ye C [239], in which type O blood donors were reported to have a higher infection rate, and type $\mathrm{AB}$ showed relatively lower rate. Uneven distribution with blood type was also seen in Rui ZL's study, in which type A blood donors were reported to have a higher rate [131]. However, the mechanism between blood type and HCV infection remained undefined, which may be related to red cell immune adherence function among persons with different blood types, but it need further study [131].

Numerous research has showed that paid blood donors are more likely to be infected with $\mathrm{HCV}$ than both employer-organized donors or true voluntary donors. Our results confirmed that $\mathrm{HCV}$ infection rate in paid blood donors was significantly higher than in voluntary blood donors ( $15.53 \%$ vs $0.97 \%$ ). Those paid donors who were attracted by high compensation and chose to donate blood in illegal blood stations, also risked a greater risk of cross-contamination. The prevalence rate among plasma donors was significantly higher than among whole blood donors (33.95\% vs $7.90 \%$ ), possibly due to cross-contamination of blood collection equipment by HCV positive plasma donors [77]. The elimination of paid plasma and whole blood donation could contribute to a reduction in $\mathrm{HCV}$ infection among blood donors.

Several limitations in our study need to be addressed. First of all, the studies were observational and blood donors were not randomly chosen. Therefore selection bias and confounding seems inevitable. Secondly, many of our data were extracted from studies written in Chinese, which makes it difficult for non-Chinese reviewers, editors, and readers to trace back to the original materials. Thirdly, our ability to assess study quality was limited by the fact that many studies failed to offer detailed information of selected subjects or valid data on important factors. Besides, as with all meta-analyses, this study has potential limitation of publication bias. Negative trials are sometimes less likely to be published. However, we have confidence on our results since the included literatures were mostly from multi-resources and had large sample size, which should reduce publication bias to some extent.

\section{Conclusions}

This meta-analysis provides a comprehensive and reliable data on the prevalence and trend of $\mathrm{HCV}$ infection among blood donors. The pooled epidemic rate of $\mathrm{HCV}$ infection has rapidly decreased after 1998, though some provinces still showed relatively high prevalence. Achievements and lessons in previous work indicated that long-term, comprehensive and effective interventions and preventions are urgently needed. In particular, implementing and enforcing the "Blood Donation Law" and promoting HCV screening, diagnosis, and treatment among blood donors are very important measures to control the transmission of $\mathrm{HCV}$ infection. In addition, the key to reduce the incidence of $\mathrm{HCV}$ infection among blood donors is to encourage true voluntary blood donation, pay more attention to exclude those high-risk persons from the volunteers, and eliminate cross-infection completely when collecting single plasma.

\section{Acknowledgements}

This work was supported by the National Mega-project of Science Research (2008ZX10002-013 and 2009ZX1004-904). We appreciate Katie Reilly for revising the paper.

\section{Author details}

${ }^{1}$ Department of Epidemiology and Biostatistics, School of Public Health, Nanjing Medical University, Nanjing 210029, PR China. ${ }^{2}$ The First Clinical Medical College of Nanjing University, Nanjing 210029, PR China.

${ }^{3}$ Department of Epidemiology, National Center for AIDS/STD Control and Prevention, Chinese Center for Disease Control and Prevention, Beijing 100050, PR China.

\section{Authors' contributions}

XFG, QC, XS, JS and RBY were involved in the design, literature searching, assessment of study quality, and drafted the manuscript. JS and RBY revised critically the manuscript. XFG, QC and ZHP performed statistical analysis and critically revised the manuscript. KQD, NL and XC constructed the maps. LW and NW critically revised original study design and the manuscript. All the authors read and approved the final manuscript.

\section{Competing interests}

The authors declare that they have no competing interests.

Received: 6 October 2010 Accepted: 9 April 2011 Published: 9 April 2011

\section{References}

1. Alter MJ: Epidemiology of hepatitis C virus infection. World J Gastroenterol 2007, 13:2436-41.

2. Perz JF, Farrington LA, Pecoraro C, Hutin YJF, Armstrong GL: Estimated global prevalence of hepatitis $C$ virus infection. 42nd Annual Meeting of the Infectious Diseases Society of America Boston: MA USA; 2004. 
3. Liu $L$, Wei L: Epidemiology of hepatitis C virus. Infectious Disease Information 2007, 20:261-264, [in Chinese].

4. Prati D: Transmission of hepatitis $C$ virus by blood transfusions and other medical procedures: a global review. J Hepatol 2006, 45:607-16.

5. Chen YT, Jiang JJ: Epidemic situation of hepatitis C virus. Strait Journal of Preventive Medicine 2009, 15:19-21, [in Chinese].

6. Shang G, Seed CR, Wang F, Nie D, Farrugia A: Residual risk of transfusiontransmitted viral infections in Shenzhen, China, 2001 through 2004. Transfusion 2007, 47:529-39.

7. Shan H, Wang JX, Ren FR, Zhang YZ, Zhao HY, Gao GJ, Ji Y, Ness PM: Blood banking in China. Lancet 2002, 360:1770-5.

8. Wang Y, Tao QM, Zhao HY, Tsuda F, Nagayama R, Yamamoto K, Tanaka T, Tokita $\mathrm{H}$, Okamoto H, Miyakawa Y: Hepatitis C virus RNA and antibodies among blood donors in Beijing. J Hepatol 1994, 21:634-40.

9. Zhao SM, Jiang TL, Gao FX, Lu L, Zheng HQ, Hu J, Fan YH, Li B, Xiao RR, Yury K: Analysis of true voluntary blood donors with anti-HCV prevalence and implications for donor management in Chongqing, China. Transfus Med 2007, 17:210-1.

10. Freeman MF, Tukey JW: Transformations related to the angular and square root. Ann Math Stat 1950, 21:607-611.

11. Qian HZ, Vermund SH, Kaslow RA, Coffey CS, Chamot E, Yang Z, Qiao X, Zhang $Y$, Shi $X$, Jiang $Y$, Shao $Y$, Wang N: Co-infection with HIV and hepatitis $\mathrm{C}$ virus in former plasma blood donors challenge for patient care in rural China. AIDS 2006, 20:1451-2.

12. Adams V, Erwin K, Le PV: Public health works: Blood donation in urban China. Social Science \& Medicine 2009, 68:410-418.

13. $H Z Q$, Yang $Z$, Shi $X$ : Hepatitis $C$ virus infection in former commercial plasma blood donors in rural Shanxi province, China The China Integrated Programs for Research on AIDS. J Infect Dis 2005, 192:1681-2.

14. Chen YD, Liu MY, Yu WL, Li JQ, Peng M, Dai Q, Liu X, Zhou ZQ: Hepatitis C virus infections and genotypes in China. Hepatobiliary Pancreat Dis Int 2002, 1:194-201.

15. Wang Y, Chen HS, Fan MH, Liu HL, An P, Sawada N, Tanaka T, Tsuda F, Okamoto $\mathrm{H}$ : Infection with $\mathrm{GB}$ virus and hepatitis $\mathrm{C}$ virus in hemodialysis patients and blood donors in Beijing. J Med Virol 1997, 52:26-30

16. Liu S, Figueroa P, Rou K, Wu Z, Chen X, Detels R: Safety of the blood supply in a rural area of China. J Acquir Immune Defic Syndr 2010, 53:23-6.

17. Tao QM, Wang $Y$, Wang $H$, Chen WR, Sun $Y$, Meng $Q$, Watanabe J, Nishioka K: Seroepidemiology of HCV and HBV infection in northern China. Gastroenterol Jpn 1991, 26:156-8.

18. Shang G, Yan Y, Yang B, Shao C, Wang F, Li Q, Seed CR: Two HBV DNA +/HBsAg-blood donors identified by HBV NAT in Shenzhen, China. Transfus Apher Sci 2009, 41:3-7.

19. Shan H, Ren FR, Zhao HY, Zhang YZ, Wen GX, Yao FZ, Gao GJ, Yan LX, Jiang CF, Bai XH, Tiemuer MH, Tu YQ, Zhu FM, Zheng YR, Cui L, Liu CL, Gong XY, Lv QS, Zheng P, Ziermann R, Ness P, Wang JX: A multi-Chinese blood center study testing serologic-negative donor samples for hepatitis $C$ virus and human immunodeficiency virus with nucleic acid testing. Transfusion 2007, 47:2011-6.

20. Hao LJ: Hepatitis C infection in hospital. Rural Medicine 1996, 24:59-60, [in Chinese].

21. Liu YN, Sheng L, Liu XY, Hu JP, Cai JY, Hu WY: HCV infection in blood donors: a serological survey in Fengxian County. Shanghai Journal of Preventive Medicine 1995, 4:193-194, [in Chinese].

22. Guo ZF, Wang QW, Yang XD: HIV and HCV infection among blood donors in Dehong, Yunnan. Chinese Journal of Blood Transfusion 2009, 22:580-581, [in Chinese].

23. Gao CF, An FQ, Yue CM: Anti-HCV tested among blood donors in Baotou. Chinese Coal Industry Medicine 1999, 2:91, [in Chinese].

24. Qu XP, Gao RZ, Ding QH, Zhang W: Investigation on anti-HCV among blood donors in Hohehot. Chinese Institute of Liver Diseases Liver Diseases 1995, 3:88, [in Chinese].

25. Wang J, WU BR: HCV infection tested in blood donors in Hohehot. Chinese Public Health 1994, 10:33, [in Chinese].

26. Chong HY, Chen YG, Zhou GM: Investigation of serum anti-HCV and $\mathrm{HBsAg}$ carrier rates among various groups of population. Chinese Journal of Hospital Infection 1993, 3:225-226, [in Chinese].

27. Deng CJ, Zhang RF, Bai Y, Fan XM: Analysis of the blood test results of blood donors among different groups. Clinical Transfusion and Laboratory Medicine 2001, 3:26, [in Chinese].
28. Tao QM, Wang Y, Wang H, Chen WR, Sun Y, Meng Q: A survey of 391 cases of serum anti-HCV in different population. Journal of Beijing Medical University 1990, 22:3-5, [in Chinese].

29. Deng CJ, Wang SL, Yan AW: Indicator test results among different groups of blood donors in Beijing. Transfusion Medicine 2000, 13:78, [in Chinese].

30. Xiao K, Fan R, Chen SY: HBsAg, anti-HCV positive rate and correlation with ALT investigation among blood donors in Beijing. Transfusion Medicine 2000, 13:77, [in Chinese].

31. Chi BR, Guo XL, Liu Y: RT-PCR detection of HCV-RNA and genotyping studies. Chinese General Practice 1999, 2:96-97, [in Chinese].

32. Zhang YG, Li XQ: Anti-HIV, HBsAg, anti-HCV and the TP test results of voluntary blood donors in Hadian City. Occupational and Health 2008, 24:2435-2436, [in Chinese].

33. Li YY, Deng CY, Jiang YN, Li HH, Li YX, Wei CS, Zhan MY, Zhang WY, Li JY, Tian RG, Wang Y, Jin ZL, Xu YJ, Pu CJ: Investigation on hepatitis $C$ virus infection from blood source. Journal of Yanbian Medical College 1992. 15:205, [in Chinese].

34. Xu C, Gao RP, Zhang YX, Deng JY, Han SY: Investigation on the relationship between $\mathrm{HCV}$ infection and blood transfusion in Changchun. Journal of Bethune Medical University 1995, 21:209-210, [in Chinese].

35. Yi SH, Zhao CY, Gong YW, Li F: Investigation on hepatitis C virus infection among professional blood donors in Changchun City. Journal of Microbiology 2001, 21:64, [in Chinese]

36. Zhao H, Li DY, Cai MZ: Test of hepatitis C antibody among1246 cases of hospitalized patients. Journal of Luzhou Medical College 1999, 22:67-68, [in Chinese].

37. Xi DR, Han Y, Liu JL, Zhao J: A serological survey of hepatitis $C$ infection among 1840 blood donors. Journal of North Sichuan Medical College 1994, 9:57-59, [in Chinese].

38. Luo SE, Zhang R, Huang GY: A survey on HCV, ALT, HBsAg among 8745 blood donors in Leshan city. Shanxi Medical Laboratory 1995, 10:43-44, [in Chinese].

39. Qian LQ, Wang P: Serological analysis of unpaid blood donors in Deyang city. West China Medical Journal 2005, 19:360-361, [in Chinese].

40. Huang SG, Luo GD, Peng L: Hepatitis C infection in blood donors in Luzhou. Journal of Luzhou Medical College 1995, 18:82, [in Chinese].

41. Han DL, Liu W, Ou ZY, Liang X, Hu Q: Investigation on hepatitis C virus infection among blood donors. Practical Prevention Medicine 2001, 28:436-437, [in Chinese].

42. Liu SZ, Zhang D, Liu L: Investigation on blood donors and hepatitis C virus (HCV) infection. Chinese Journal of Health Laboratory 1994, 4:160, [in Chinese].

43. Mi XW, Pan N, Guo XX, Lai ZM: Research on hepatitis C virus infection in healthy population. Port Health Control 2000, 5:6-8, [in Chinese].

44. LI RL, Zhao L, Sun SQ: The investigation of anti-HCV infection among blood donors in Tianjin. Transfusion 1999, 12:49-50, [in Chinese].

45. Yang JP: A serological epidemiological survey on 530 volunteer blood donors infected with HCV in Dongli District, Tianjin. Occupation and Health 1999, 15:8-9, [in Chinese].

46. Miao W, Xu CG: Analysis of HBsAg, anti-HCV, anti-TP positive among unpaid blood donors in the Binhai New Area. Practical Medical Techniques 2008, 15:15-16, [in Chinese].

47. Fang SC: Serological detection and analysis on chronic liver disease and anti-HCV among blood donors. Occupation and Health 1995, 6:36-37, [in Chinese].

48. Lu YF: Anti-HCV positive rate among blood donors at Ningxia Blood bank. Ningxia Medical Journal 1996, 18:45, [in Chinese].

49. Zhao JH, Ma XY: Analysis of the result of anti-HCV test among blood donors in Yinchuan. Transfusion Medicine 2007, 20:233-234, [in Chinese]

50. Hui TH: Result analysis of anti-HCV test in 1284 blood donors. Clinical Laboratory Science 1995, 13:19-20, [in Chinese].

51. Xu LQ, Chen Z, Zhang Y, Huang GQ: Test report of anti-HCV among 719 blood donors. Anhui Preventive Medicine 1997, 3:46-47, [in Chinese].

52. Lu KQ, Chen YP: Analysis on the relationship between HBsAg, anti-HCV and blood type. Anhui Preventive Medicine 1998, 4:70, [in Chinese].

53. Lang FR, Zhang J: Serum test report on $\mathrm{HBsAg}$ and anti-HCV in different blood donors. Journal of Bengbu Medical College 1994, 12:23-24, [in Chinese].

54. Yu ZH: Prevalence survey on anti-HCV among different types of blood donors. Disease Control 1998, 2:71, [in Chinese]. 
55. Feng QC, Li SH: Test results analysis of HBsAg, anti-HCV among individual donors and unpaid blood donors in Linquan. Clinical Transfusion and Laboratory Medicine 2000, 2:17, [in Chinese].

56. Liu JQ, Li X, Wu J: Blood donors with hepatitis C virus infection in Hefei. Journal of Anhui Medical University 1994, 15:3-4, [in Chinese].

57. Ye DQ, Zheng HL, Wang YQ, Hu ZP, Wang HM, Tao LJ, Song HB: Multivariate analysis of risk factors among blood donors infected with HBV and HCV in Hefei. China Health Statistics 1997, 14:15-18, [in Chinese]

58. Zhou YS, Shi JY, Zhao QM, Du LY, Wang FY, Zhang XT, Wang HT: Investigation of HCV infection and genotype distribution in Huaibei, Anhui. China Public Health 1996, 12:204-205, [in Chinese].

59. Diao JS, Kuang HB: Report on HCV infection among blood donors in Xuanzhou. Anhui Preventive Medicine 1997, 3:61, [in Chinese].

60. Wang $J H_{\text {, }}$ Chu HY: Survey of four infectious markers in the past paid donors. Clinical Transfusion and Laboratory Medicine 2006, 8:304-305, [in Chinese].

61. Lin TL: Survey of hepatitis $C$ virus infection among blood donors in Chizhou region. Disease Control 1997, 1:149, [in Chinese]

62. Hao JH, Huang F, Ye DQ, Hu ZP, Yu XB, Jiang ZJ: Logistic regression analysis of infection with HCV among blood donors. Journal of Hospital Infection 2004, 14:5-8, [in Chinese].

63. Chen $\mathrm{NH}$, Zhang $\mathrm{H}$, Lan $\mathrm{Q}$, Li CY: Investigation on the natural population and blood donors infected with hepatitis $C$ virus. Journal of Anhui Medical University 1995, 16:57-58, [in Chinese].

64. Liao YQ, Zhu DW, Chen HX: Blood donors anti-HCV monitoring reports. Anhui Preventive Medicine 1997, 3:111-112, [in Chinese].

65. Li YX, Wu XK, Bi P, Zhang FZ, Shi XX: Serum levels of anti-HCV and risk factors among blood donors. Journal of Anhui Medical University 1996, 31:23-26, [in Chinese].

66. Ling YX, Xu HS: Investigation on hepatitis $C$ infection among three specific blood donors in Northern region. Journal of Bengbu Medical College 1996, 21:281-282, [in Chinese].

67. Zhang J: Analysis on test results of anti-HCV among 7200 blood donors in Bengbu. Hebei Medical Journal 1998, 4:96-97, [in Chinese].

68. Zhang J, Yu JH, Guan Z: Results of five infectious markers test among college students' blood donors in Bengbu. Journal of School Health 2006, 27:678-679, [in Chinese].

69. Wu J: Investigation on anti-HCV antibody among blood donors from blood bank. Journal of Wannan Medical College 2000, 19:346, [in Chinese].

70. Wang CL, Jiang GX, Kang SJ, Sheng CY, Liu HY: Six indicators of hepatitis B and anti-HCV by RIA among 1212 cases of blood donors. Labeled Immunoassays and Clinical Medicine 1994, 1:12, [in Chinese].

71. Zheng SY, Guo FJ: Analysis of hepatitis virus infection among 1494 voluntary blood donors. Chinese Journal of Pest Control 2002, 18:377, [in Chinese].

72. Ding PF, Zhang XS, Li QW, Shen FK, Zhang MH, Song W: Investigation on HCV, HBV, HIV and syphilis infection in hemophiliacs from 1992 to 2000. Chinese Journal of Thrombosis and Hemostasis 2002, 8:115-117, [in Chinese].

73. Zhao CC, Ma JC, Du QL: Survey on viral hepatitis in Heze in 1995. Documentation and Information of Preventive Medicine 1997, 3:105-107, [in Chinese].

74. Wang M, LV HJ: Investigation on syphilis, HCV, HIV infection among blood donors in Jinan from 2003 to 2005. Preventive Medicine Forum 2006, 12:619-620, [in Chinese].

75. Li M, Xu YL: The relationship between serum hepatitis $C$ virus antibody and ALT among 20294 blood donors. Shandong Traditional Chinese Medicine 1998, 38:62, [in Chinese].

76. Li JX, Zhu XZ, Peng LY: Analysis of 540 hepatitis virus infection in blood donors. Medical Education and Research 1994, 22:1-3, [in Chinese].

77. Ji Y, Ren QH, Zhu ZY, Qu DM, Qiu ZK, Li JF, Mei H, Yan HY: Analysis of hepatitis $C$ virus infection among blood donors in China. Journal of Chinese Academy of Medical Sciences 1998, 20:240-241, [in Chinese].

78. Peng LY, Zhang DJ, Zhang DC, Li JX, Bu QY: Analysis of hepatitis C infection among hemodialysis patients. Guard Army Medicine 1995, 12:6-7, [in Chinese].

79. Jiang QH, Xu GM, Zhang Y, Qu SL: Analysis of HCV cross infection among blood donors. Journal of Binzhou Medical College 1995, 18:102, [in Chinese].

80. Sheng CY, Ma YT, Wang CL, Dai F, Liu HY, Kang SJ: Radioimmunoassay analysis of HCV antibody in blood donors with plasmapheresis. Radiation Immunology 1995, 8:38-39, [in Chinese].
81. Guo YW, Yu CY, Zheng KJ, Sun RT: Investigation on hepatitis C virus infection among different population in Weihai. Documentation and Information of Preventive Medicine 1997, 3:217, [in Chinese].

82. Jin D, Sun WJ, Qi XD: Analysis of blood plasma detection results among unpaid donors in Weihai. Chinese and Foreign Health Care 2008, 34:185-186, [in Chinese].

83. Liu SZ, Fu JH, Kang DM, Su SL, Huang T: Suvey of hepatitis C virus infection among blood donors in a certain area of Shandong Province. China's Primary Health Care 2000, 10:51-52, [in Chinese].

84. Peng HB, Xue CJ, Zhang SQ: Detection of HCV antibody among blood donors in Yimeng, Shandong. Clinical Focus 1995, 12:571, [in Chinese].

85. Du GJ, Wang YN, Li XP, Cao MY, Zhang JM: Detection and comparison of HCV infection in voluntary blood donors from military in Gansi Region. Journal of Lanzhou Medical College 2003, 29:32-33, [in Chinese].

86. LI GJ, Huang HZ: Investigation of HCV infection among blood donors in our region. Chongaing Medicine 1996, 4:243, [in Chinese].

87. Li J, Zhang MZ, Liu CZ, Gao LX, Zhang GY: Blood detection results of unpaid and individual blood donors analyzed. Journal of Hospital Statistics 1996, 3:23-25, [in Chinese].

88. Wu F, Liu CL: HCV infection and health education among blood donors in rural areas, Taian. Chinese Rural Health Service Administration 1997, 17:54, [in Chinese].

89. Hou PQ: Analysis of blood-borne transmitted diseases among former paid blood donors in Taian. Journal of Taishan Medical College 2007, 28:9-11, [in Chinese].

90. Zhu HF: Epidemiological investigation of blood-borne virus infection and human herpes virus type 8 prokaryotic expression vectorconstruction among voluntary blood donors in Jinan. Journal of Shandong University 2008, 47, [in Chinese].

91. Zhao FY, Shi XG, Zhen JZ, Liu MX, Chu N: Investigation of HCV infection among plasmapheresis donors in Jining City. Journal of Preventive Medicine 1994, 5:266, [in Chinese].

92. Dong JH, Liu FS: Structure of blood donors and statistical analysis of blood-borne transmitted diseases in Yantai. China Health Statistics 2005, 22:90-91, [in Chinese].

93. Wang YC, Han WQ, Sun Y, Gong LF, Lin WL: Suvey on HCV antibody among hepatitis patients and blood donors in Yantai. Journal of Preventive Medicine 1994, 5:280, [in Chinese].

94. Zhen SP, Zhuang KY, Zhang YL, Shi YX, Zhao FY, Zhen JZ: Protective effect of anti-HCV screening among plasmapheresis donors evaluated. China Public Health 1995, 6:255-256, [in Chinese].

95. Liu RH: Investigation of HAV, HBV, HCV infection among professional blood donors. Ningxia Medical Journal 1999, 8:467-469, [in Chinese].

96. Yu Q, Zhang J, Hou PQ: Detection of infectious diseases among AIDS high-risk groups. Chinese Health Service Management 2006, 7:443-444, [in Chinese].

97. Zhang CS, Han JY, Pang LL: Investigation of hepatitis C virus infection among blood donors in Heze. Clinical Transfusion and Laboratory Medicine 2000, 2:55, [in Chinese].

98. Zhang WQ, LV R, Gao SZ, Zhao BW, Zhang SH, Shao JJ: Investigation of $\mathrm{HCV}$ infection among blood donors and HCV contamination among blood products in Qingdao. Journal of Qingdao Medical College 1995, 3:201-204, [in Chinese].

99. Shi SS, Guo WD, Guo YC, Zhu XD: Serum anti-HCV detection in 1043 blood donors. Shanxi Traditional Chinese Medicine 1994, 23:358, [in Chinese].

100. Zhao LF, Lang LJ, Zhang LR, Xiang SJ: Detection of HCV infection among blood transfusion, liver cancer and various types of viral hepatitis. Journal of Epidemiology 1994, 6:354-356, [in Chinese].

101. Huang SL, Liang JP: Anti-HCV monitoring results among blood donors. Disease Control 1997, 3:196-197, [in Chinese].

102. Guo XL, Wang NC, Zhang B: Preliminary Analysis of the HCV Infection among Certain Population in Shanxi Province. China Health Management 2010, 26:288-289, [in Chinese].

103. Li QS, Xiang SJ, Lang LJ, Zhang LR: Detection of anti-HCV among blood donors and patients with post-transfusion hepatitis. Shanxi Traditional Chinese Medicine 1992, 4:213-214, [in Chinese].

104. Zhang XF, Liao QW, Zheng JP: Survey of HCV infection among individual and voluntary blood donors in Yuncheng. Practical Medical Techniques 1999, 10:767, [in Chinese]. 
105. Zuo JL, Niu LB: Correlation analysis of HBV, HCV and ALT among voluntary blood donors in Changzhi. Asia-Pacific Traditional Medicine 2008, 12:147-148, [in Chinese].

106. Chen C: Detection of serum HCV antibody among 10,000 blood donors. Guangzhou Pharmaceutics 1994, 1:52, [in Chinese]

107. Chen GH: Investigation of anti-HCV in 3652 blood donors. Guangdong Medical Journal 1995, 3:160, [in Chinese].

108. Long YY: Analysis of serum HBsAg and anti-HEV detection results in 6023 blood donors. Journal of Guangdong Medical College 2003, 2:172, [in Chinese].

109. Wu JN, Xia CY: The level of ALT could not be regarde as an indicator of HCV infection in blood donors. Guangzhou Pharmaceutics 2004, 6:59-60, [in Chinese].

110. Zhou YY, Shang GF, Yang LX, Qi ZB, Xu X, Wu Y: Detection of HCV core antigen as a "window period" infection markers. Transfusion 2004, 3:162-163, [in Chinese].

111. Rong $X$, Xia WJ, Wang M, Wang YZ, Zhen YR, Ye X, Luo GP, Wang CX, Bei CH, Fu YS: Seroepidemiological studies of HCV among first-time volunteer blood donors in Guangzhou, China. Transfusion 2009, 11:883-885, [in Chinese].

112. Yung $Y, X U L Y, G U X H$ : Analysis of ALT testing results and other epidemic inexes of the free blood donors. Practical Medical Techniques 2005, 12:1606-1608, [in Chinese].

113. Nie DM, Wang F, Shang GF, Ye XL, Yang LX, Zhou H: Retrospective analysis of the infectious status of hepatitis $C$ virus of blood donors in Shenzhen. Journal of Medical Laboratory 2006, 2:118-120, [in Chinese].

114. Zhou P, Luo J, Xie CY: Study on the infections status of Hepatitis C virus of first-time blood donors in Zhanjiang. Journal of Hainan Medical College 2006, 2:115-117, [in Chinese].

115. Du YM, Li YX: Detection of anti-HCV among blood donors and its significance for hepatitis C infection control. Practical Medicine 1997 13:154-155, [in Chinese].

116. Tang ZZ, Fang ZF, Liang YF, Huang CS: Recheck analysis for anti-HCV of source plasma in Guangxi Province during 1993 and 1995. Guangxi Preventive Medicine 1997, 3:30-32, [in Chinese]

117. Jiang FS: Review the results of anti-HCV detection among blood donors from 1998 to early 1999. Guangxi Preventive Medicine 2000, 6:255, [in Chinese].

118. He FQ, Wang JK, Li MY: Hepatitis C virus infection among 200 blood donors. Medical Anthology 1995, 6:518-519, [in Chinese].

119. Zhou ZD, Huang LH: Analysis of HCV antibody among 27,518 blood donors of Zhuang nationality. Journal of Preventive Medicine 2000, 7:348-349, [in Chinese].

120. Li RY: Analysis of anti-HCV detection results among 280 blood donors. Journal of Youjiang Medical College 1996, 4:62-63, [in Chinese].

121. Chen $X Z$, Tan QF, Huang Y: HCV infection among voluntary blood donors of multi-ethnic in research. Chongaing Medicine 2009, 12:1443-1444, [in Chinese].

122. Huang SX: Analysis of HBV and HCV infection status among blood donors in Debao. Youjiang Medicine 1996, 1:25, [in Chinese].

123. Man HT: Report on blood donors infected with HBV and HCV. Journal of Guilin Medical College 1996, 3:84-85, [in Chinese].

124. Zheng XH: Report of hepatitis $\mathrm{C}$ antibody detection among 822 cases of blood donors. Journal of Shihezi Medical College 1997, 19:14, [in Chinese].

125. Wang DL: HBV and HCV infection monitoring among 100 professional donors in Yili, Xinjiang. China Public Health 1995, 2:94, [in Chinese].

126. Tang XM, Dou J, Chen YH, Mou XY, Song QL: Investigation of HCV infection and HCV genotype distribution among Xinjiang Uygur populations. China Public Health 1998, 1:11-12, [in Chinese].

127. Dai Rd, Zhao XD, Zhang YP, Zhang RL: Serum HBsAg, anti HCV, anti-HIV detection reports in 16,845 blood donors. Journal of Youjiang Medical College 2004, 1:47-48, [in Chinese]

128. Xu YN, Li ZY, Qian YZ, Zhang KZ: ALT, HBsAg and anti-HCV detection results analyzed in 1692 blood donors. Journal of Nanjing Medical University 1994, 2:261, [in Chinese].

129. Xing WG, Xu HY, Ma Z, Zhen HJ: HCV RNA assessment by PCR technique for screening post-transfusion HCV infection among blood donors. Journal of Hepatology 2002, 3:52-53, [in Chinese].

130. Rui HF, Sun HX: Serological survey on hepatitis $C$ virus infection among blood donors with different donation types. Clinical Focus 1995 21:996-997, [in Chinese].
131. Rui ZL: The relationship of hepatitis $C$ virus infection and blood types explored preliminarily. Journal of Zhenjiang Medical University 1998, 8:493, [in Chinese].

132. Di LM: Serological survey on hepatitis C virus. Modern Preventive Medicine 1996, 23:55

133. Wang RS: Coinfection of HBV and HCV infection and its control measures in hospitals. Harbin Medicine 1994, 3:36-37, [in Chinese]

134. Sun NX, Sun QJ, Zhang YX, Tan W, Han YP, Liu T: The prevalence of HCV infection among voluntary blood donors in Nanjing. Transfusion Medicine 2001, 14:309, [in Chinese].

135. Li HL, Li G, Gong XP: Investigation of HCV infection among different populations in Nanjing. Clinical Laboratory Science 1994, 3:142-143, [in Chinese].

136. Wang DW, Liu XY: Part of the population infected with Hepatitis C virus in Nanjing analyzed. Jiangsu Traditional Chinese Medicine 1994, 20:48, [in Chinese].

137. Jiang F, Yao DF, Zhang H, Wei Q, Xiao MB, Huang JF, Meng XY: The status of hepatitis $C$ virus infection among blood donors in Nantong. Medical Journal 1998, 1:6-7, [in Chinese].

138. Yao RN, Zhang JH, Huang XJ, Yang Q, Cao Q, Jiang XC: Technique of detection of hepatitis $C$ core antigen used in safety blood transfusion. Journal of Experimental Hematology 2006, 3:617-618, [in Chinese].

139. Xia YJ: Anti-HCV positive rate among unpaid blood donors in the primiary investigation. Traffic Medicine 2002, 16:216, [in Chinese].

140. Zhou SX, Xu DY, Shi LX, Fu YH, Li YQ: HCV infection among blood donors investigated in Yizheng, Jiangsu. China Public Health 2000, 16:609, [in Chinese].

141. Bao Y, Huo QP, Shu HS, Yu MJ, Guo GS, Hong DQ: Investigation on HCV infection and risk factors in Jiangsu Province. Endemic Disease Bulletin 1994, 4:33-35, [in Chinese].

142. Qu SD, He TL, Huang JX, Zhou XH, Dong XH: Hepatitis C virus infection in Haiyan County. Journal of Preventive Medicine 1994, 4:51-52, [in Chinese].

143. Shen L, He JP, Liu XQ, Cai RT, Shen Y, Du JX: Long-term changes of liver function and blood lipid in blood donors infected with HCV. Journal of Clinical Hepatology 2009, 4:298-299, [in Chinese].

144. Li SR, Qiu YZ, Yang JW, Hua RZ: Logistic regression analysis of influential factors of HCV infection in one blood donors aggregated area. Journal of Preventive Medicine 2005, 6:618-620, [in Chinese].

145. Yang DM, Ye SL: Seroepidemiological analysis of HCV infection in professional blood donors. Journal of Preventive Medicine 1995, 4:19-20, [in Chinese].

146. Wang AX, Sheng RY: A prospective study on post-transfusion hepatitis $C$. Journal of Internal Medicine 1996, 10:12-15, [in Chinese]

147. Qi HS, Wang L, Xu MT, Li YC, Zhao WB: Study of HBV, HCV infection among blood donors in Ganyu. Jiangsu Preventive Medicine 2000, 5:73-74 [in Chinese].

148. Hua RZ, Li SR, Qiu YZ, Zhong ZH, He XY: Investigation on rural blood donors and HBV, HCV, and HIV infection in Zhenjiang. Practical Prevention Medicine 2004, 15:46-48, [in Chinese].

149. Zhan TR, Yang XF: Suvey of anti-HCV among blood donors in Jiujiang Journal of Medical Laboratory 1995, 4:26-27, [in Chinese].

150. Zha XZ: Investigation of HCV antibody status in Wuyuan. Journal of Medical Laboratory 1997, 15:30, [in Chinese].

151. Yu SK, Yi DY, Sun LH: Detection of hepatitis $C$ virus antibody in patients with sporadic viral hepatitis. Jiangxi Traditional Chinese Medicine 1992. 6:333-335, [in Chinese]

152. Fang CF, Miao YP, Huang ZJ: Survey on HTLV infection among blood donaors in Jiangxi. Clinical Transfusion and Laboratory Medicine 2004, 2:135, [in Chinese].

153. Xiong $Y$, et al: A seroepidemiological study on HCV in blood donors in Jiangxi province. Journal of Preventive Medicine 2003, 1:28-30, [in Chinese]

154. Shu QY: Survey of anti-HCV among blood donors in Yingtan. Journal of Medical Laboratory 1997, 2:20, [in Chinese]

155. Shi DY, Du M, Ma JP: Clinical significance of hepatitis $C$ virus antibody detection. Clinical Laboratory Science 1994, 12:144-145, [in Chinese].

156. An ZY, Liu X, Wang DJ: Serological detections of HCV antibody in 1024 blood donors. Preventive Medical Information 1996, 1:23-24, [in Chinese].

157. Song RH: A suvey from 2004 to 2008 on HCV infection among blood donors in Shijiazhuang. Chinese Journal of Blood Transfusion 2009 , 22:746-747, [in Chinese]. 
158. Ren GC, Wu Q, Chen XY: Serological anti-HCV detection in 664 blood donors. Beijing Military Medicine 1994, 2:147-148, [in Chinese].

159. Sun YD, Chen SL, Chen XR, Sun DG, Wang SY, Chen Z, Meng DZ, Zhuang H, Liu CB, Xu ZY, Margolis H, Liu CY, Wang ZG, Ma XW, Wang DJ, Shi WH, Jia ZG, Wang SC, Qiu HM: Epidemiological and serological study on hepatitis $C$ virus infection in plasmapheresis donors. Journal of Epidemiology 1991, 12:327-330, [in Chinese].

160. Zhao Y, Shi L, Chen SL, Zhang ZK, Li KY, Deng JH, Tian WC: Cross infection of hepatitis $\mathrm{C}$ virus among plasmapheresis donors in investigation. Journal of Experimental and Clinical Virology 1995, 2:125, [in Chinese].

161. Wang DJ, Chen SL, Sun YD: Serological trace of HBV and HCV infection among blood donors in Gu'an. Transfusion 1992, 4:180-183, [in Chinese].

162. Sun DG, Chen CR, Wu JY, Liu CB, Zhuang H: Comparison of hepatitis C prevalence in plasma donors before and after the straightening of blood donation centers. China Public Health 1991, 1:3-5, [in Chinese].

163. Li CM, Liu ZS, Li ZH, Zhang YX: Serological study of hepatitis C virus infection in blood donors in Hebei. Journal of Experimental and Clinical Virology 1994, 2:179, [in Chinese].

164. Yu M, Tian XL, Han ZH, Wan H, Li WG, Gong WB, Wei L, Xu XY: Findings of anti-HIV tests in persons infected by HCV after blood transfusion in one county of Hebei Province. Chinese AIDS 2003, 4:197-198, [in Chinese].

165. Zhao YL, Sun YD, Meng ZD, Liu XL, Qian XQ, Yan TB, Sun DG, Kang TJ, Tian C: Investigation of HCV infection and analysis of screening results among blood donors in Hebei Province. Shanghai Preventive Medicine 1995, 10:455-457, [in Chinese].

166. Chen SL, Tian W, Meng ZD, Sun YD, Yang YP, Liu CB, Li CM: Seroepidemiological study of hepatitis $\mathrm{C}$ virus infection in one blooddonator aggregated base in Hebei Province. Hebei Traditional Chinese Medicine 1993, 2:66-68, [in Chinese].

167. Zhao YL, Zhang AP, He B, Zhang CQ, Sun YD, Zhang WM, Liu CY, Tian C, Liu HB, Kang TJ, Niu JZ, Xu DG, Sun YD: Survey of HCV infection among blood donors of Hebei Province. Disease Surveillance 1994, 12:333-335, [in Chinese].

168. Zhang HH, Wang QM, Liu XL: Epidemiological investigation of HCV infection among blood donors in Zhao County, Hebei Province. Documentation and Information of Preventive Medicine 1995, 2:389-390, [in Chinese].

169. Chen SL, Meng SD, Sun YD, Chen XR, Sun DG, Wang ZG, Zhuang H: Risk factors of hepatitis $C$ virus in plasmapheresis donors analyzed. Journal of Public Health of China 1992, 3:151-152, [in Chinese].

170. Bian BY, Cai HM, Li P: Survey on blood donors and hepatitis $C$ antibody. Journal of Zhangjiakou Medical College 1994, 3:53, [in Chinese].

171. Zhang SY: Conditional logistic regression analysis of the influential factors of $\mathrm{HCV}$ infection in one blood-donator aggregated village. Documentation and Information of Preventive Medicine 2000, 1:3-4.

172. Zhang SY, Hou T, Wang DJ, Li SB, Liu XL, Zhao G: Investigation of hepatitis $\mathrm{C}$ virus among blood donors in Shijiazhuang City. Disease Surveillance 1995, 10:305-306, [in Chinese].

173. Sun YD, Zhao YL, Liu XL, Yan TB, Tian W, Liu HW, Qian XQ: Anti-hepatitis C virus screening to prevent hepatitis $C$ virus infection in blood donors. Journal of Internal Medicine 1995, 10:696-699, [in Chinese].

174. Hu LY, Wang QY, Hu YZ: Preliminary analysis of anti-HCV detections and infectious factors 1128 blood donors. Journal of Henan Medical University 1995, 30:54-55, [in Chinese].

175. Geng CH, Cui WH: Anti-HCV detection of 2045 blood donors and 206 non-donors. Guard Army Medicine 1994, 2:115, [in Chinese].

176. Qiu PF, Hu SL, Ren SL, Chen HL, Guo TP, Wu QL, Shao WX: Risk facts of HCV infection among 500 blood donors analyzed. Journal of Shanghai Medical University 1994, 21:41-45, [in Chinese].

177. Xuan QS: Investigation of HCV infection in blood donors with $A, B, O$, or AB blood type. Preventive Medicine 1994, 6:357-358, [in Chinese].

178. Wen T, Chen SG, Liu YZ, Li WS: Detection of hepatitis C virus RNA and serum markers. Cellular and Molecular Immunology 2003, 19:375-376, [in Chinese].

179. Wei W: Epidemiological analysis of HIV, HCV, HBV infection among blood donors of offering plasma in Xinyang. Practical Prevention Medicine 2006, 6:347-348, [in Chinese].

180. Ma HL, Su F: The hospital infection of viral hepatitis analyzed. Chinese Journal of Infection Control 2003, 2:315, [in Chinese].
181. Wang SP, Ding H, Zhang HQ, Ru YZ, Yang JC, Zhao QK, Geng HH, Zhu WF: The investigation report of hepatitis $C$ virus among plasmapheresis donors. Journal of Epidemiology 1994, 15:71-73, [in Chinese].

182. Guo BC, Wang QB: Analysis of hepatitis C antibody detection results among blood donors in Anyang. Shanghai Medical Laboratory Science 1994, 2:120, [in Chinese].

183. Wang SP, Zhu WF, Qi ZB, Gu JL, Li DY, Feng DY, Ding H: Comparison of $\mathrm{HCV}$ prevalence in plasma donors before and after the implementation of anti-HCV screening. China Public Health 1996, 5:203, [in Chinese].

184. Li QL, Fan FE, Ren L, Su B: Investigation of hepatitis C virus infection among blood donors in Kaifeng. Medical Research in Kaifeng 1994, 1:65-67, [in Chinese].

185. Gao Q: Suvey of HCV infection among different populations in Xinxiang Railway Area. Journal of School Health 1998, 6:344-345, [in Chinese].

186. Wang B, Liu GF, Zhang Y: Epidemiological analysis of blood donors infected with HCV. Journal of Hospital Infection 2002, 1:43-44, [in Chinese]

187. Li J, Cheng H, Qian X, Gao MY, Cao GH, Chen CK, Gao YN, Jiang QW: An epidemiological study on HBV and HCV infection among former paid blood donors in one village of Henan province. Journal of Fudan University (Medical Sciences) 2007, 1:71-75, [in Chinese].

188. Feng $X H$, Li DS, Wang CX: The distribution of hepatitis $C$ virus infection in Henan Province analyzed. Journal of Public Health of China 1995, 2:87, [in Chinese].

189. Zhang CJ, Li JC: Investigation of anti-HCV prevalence in whole blood donors and plasma donors. Shandong Traditional Chinese Medicine 2003, 43:31, [in Chinese].

190. Wang Y, Zhang XR, Ma QS, Li J, Li W: Investigation of anti-HCV in 1180 cases of blood donors. Clinical Hepatology 1995, 1:29-30, [in Chinese].

191. Luo B: Epidemiology of blood donors and hepatitis C. Rural Medicine 1998, 4:38-39, [in Chinese].

192. Zhang BW, Xing PQ, Guo RH, Zhao R, Fang JH: Detection and significance of HCV core antigen among blood donors. Chinese Journal of Biologicals 2002, 5:286, [in Chinese].

193. Zhao J, Wen T: The relationship of increase of alanine aminotransferase and HCV infection among blood donors. Misdiagnosis 2003, 10:1513-1514, [in Chinese].

194. Li JZ, Chen L, Lv PL: Investigation of hepatitis C virus among 2642 professional blood donors. People Medicine 1994, 2:17-18, [in Chinese].

195. Huang ZJ, Zhu XY: Investigation of HIV/HCV infection rate among paid blood donors in Yudong county. Medical Informatics 2009, 10:2090-2093, [in Chinese].

196. Li FH, Yang DL, Huang YC, Wang HK: Satus of HCV infection in blood donors and recipients who have recivecd anti-HCV positive blood. Journal of Hospital Infection 1995, 4:6-9, [in Chinese].

197. Li G: Different groups of HCV infection and HCV genotype in Zhengzhou. Misdiagnosis 2004, 3:343-345, [in Chinese].

198. Yang BX, Li WS, Liu YZ: The survey of anti-HCV positive rate among unpaid blood donors in Zhengzhou. Occupation and Health 2005, 21:1523-1524, [in Chinese].

199. Zhang WZ: Investigation of anti-HCV in 2903 female blood donors. Preventive Medicine 1998, 2:86-92, [in Chinese].

200. Wang CX: Preliminary detection of 645 cases of hepatitis $C$ among blood donors. Journal of Wenzhou Medical College 1993, 79, [in Chinese].

201. Wang FC, Shi ZY, Cai J, Su J: Evaluation on the use of detection of hepatitis $\mathrm{C}$ core antigen for screening blood donors. Journal of Experimental and Clinical Virology 2007, 4:389-390, [in Chinese].

202. Yin HF, Hou JY: Strictly detection of HBsAg and anti-HCV among blood donors to prevent post-transfusion hepatitis. Journal of Youjiang Medical College 1998, 3:184, [in Chinese].

203. Huang QY: Unpaid blood donors blood-borne infectious disease monitoring and analysis in Jiaxing. PLA Preventive Medicine 2005, 2:111-112, [in Chinese].

204. Meng ZH, Xuan W, Han JJ: Investigation of HBV, HCV Infection of bank blood. Journal of Traditional Chinese Medicine 1994, 40, [in Chinese].

205. Wang WH, Hu KY, Wang H: Retrospective analysis of blood detection results among unpaid blood donors in Kaihua 2001-2005. Transfusion Medicine 2007, 20:400-401, [in Chinese].

206. He L, Zheng CH, Lin YL: Unpaid blood donors infected with hepatitis C virus and syphilis analyzed. Chinese Health Detection Journal 2007, 17:938-939, [in Chinese]. 
207. He TL, Qu SD, Huang JX, Zhou X, Dong XH: Investigation on hepatitis C virus (HCV) infection among blood donors in Haiyan. Practical Prevention Medicine 1994, 4:12, [in Chinese].

208. Zhang YQ, Zhu RC, Zhou LP: Hepatitis C virus infection in blood donors analyzed. Ningbo Medicine 1997, 9:81, [in Chinese].

209. Xu ZG, Xu ZP, Ceng YL, Ye XH, Chen Z, Chen MH: Investigation of hepatitis $B$ and hepatitis $C$ virus infection among blood donors (37 cases). Journal of Medicine 1994, 6:55-56, [in Chinese].

210. Jin ZL, Chen SQ, Shi ZY, Fang L, Chen IP, Cai J, Ji CL, Wang FC: Epidemiological study of hepatitis $C$ virus infection in plasmapheresis and blood donors. Journal of Epidemiology 1995, 4:234-236, [in Chinese]

211. Tang SX, Ma XK: Seroepidemiological studies on HCV infection in some area of China. Journal of Epidemiology 1993, 14:271-274, [in Chinese].

212. Jin HC, Zhou XC: Seroepidemiological survey of hepatitis $C$ virus among blood donors. Hubei Journal of Preventive Medicine 1998, 9:26, [in Chinese]

213. Zhang YY: Study of HCV antibody with immunoenzymatic and recombinant immuno-blot method among healthy blood donors in China. Journal of Tongji Medical University 1992, 1:55, [in Chinese].

214. Yu CY, Liang M, Shu ZJ, Yao ZM: Blood donors and hepatitis C virus infection and the relationship between post-transfusion hepatitis. Traditional and Western Medicine on Liver Diseases 1994, 1:26-27, [in Chinese]

215. Zhang XF, Tang H, Luo XG, Chen HP: Study on the Serological states of $\mathrm{HCV}$ and HBV among HIV blood donors. Chinese Journal of AIDS \& STD 2002, 4:229-230, [in Chinese].

216. Peng L, Tian HQ: Investigation on coinfection of sphilis and HCV. Chinese Medicine 2007, 16:108, [in Chinese].

217. Hao LJ, Guo LS, Zhang YC, Theilmann L, Yang ZC, Takada: Investigation on serum HCV infection among different population inWuhan. Journal of Tongji Medical University 1992, 3:145-149, [in Chinese].

218. Wu XG, Xu CM: Survey on anti-HCV among certain groups of Shashi. Journal of Epidemiology 1993, 14:331-333, [in Chinese].

219. Zhang FL, Xie B, Xu SH, Deng LQ: Hepatitis C virus antibody among 994 blood donors investigated in Yunmeng, Anlu, and Xiaogan area of Hubei Province. Journal of Epidemiology 1994, 1:62, [in Chinese].

220. Li FH, Yang DL, Yu ZQ, Wang YK, Xu XL, Dai F, Hao LJ: Dynamic study of hepatitis $C$ virus infection among blood donors in different parts of Hubei Province. Wuhan Medical Journal 1996, 20:146-147, [in Chinese].

221. Hu GQ: Serum detection of anti-HCV and HCV RNA screening of HCV infection among blood donors in research. Chinese Journal of Ecology 1999, 2:55, [in Chinese].

222. Li CZ, Hu GL, Zhang Z, Tan DM, Wu LF, Tang DX: Investigation on hepatitis $C$ virus infection among high-risk populations. Practical Prevention Medicine 1996, 3:132-133, [in Chinese].

223. Wan YS, Zhou XY: Profiles of hepatitis $C$ virus infection among blood donors in Zhuzhou. Practical Prevention Medicine 1998, 4:437, [in Chinese]

224. LV YF, Yin P, Liu TY: Analysis on quality control of blood in blood banks in a five-year program in Human province. Journal of Epidemiology 2003, 7:42-44, [in Chinese].

225. Zhou XH: Analasis of ungraded blood samples among voluntary blood donors in Xiangtan City. Practical Prevention Medicine 2008, 4:1100-1101, [in Chinese].

226. Chen JM, Deng N, Liu WP: HCV antibody among blood donors in Xiangtan City analyzed. Practical Prevention Medicine 1996, 4:195, [in Chinese].

227. Chen X, He JM, Wu HQ, Wang ZX, Huang YM, Wang GQ, Cheng YD: A seroepidemiological and behavior factors study of HIV, HCV, HBV, and syphilis among commercial blood donors. Practical Prevention Medicine 1999, 3:17-19, [in Chinese].

228. Zeng JG, Liu LH, Zhu ZH, Zhu SY: HCV antibody among blood donors in research in two cities (districts) of Yiyang. Practical Prevention Medicine 1998, 5:151, [in Chinese].

229. Li XQ, Chen BY, Tan MK: Investigation of HBV and HCV infection among junior college students and technical students in Chenzhou. Practical Prevention Medicine 2001, 6:422, [in Chinese].

230. Liao K, Luo J, Zou MX: A suvey of the prevalence of HCV blood donors in Changsha. Practical Prevention Medicine 2008, 3:730-732, [in Chinese].

231. Yang LF: Analysis of HCV infection among 2210 outpatients. Qinghai Medical Journal 2001, 31:40-41, [in Chinese].

232. Wang YN, Du GJ, Jiang SW: HCV infection among volunary blood donors in research in Lanzhou. Northwest National Defense Medical Journal 2008, 29:148, [in Chinese].
233. Guo ZH, Zhen BD, Xie C: Hepatitis A, B, C, and D virus infection among professional blood donors in research in Lanzhou. Journal of Lanzhou Medical College 1996, 1:70-71, [in Chinese].

234. Zhen $B D$, Yang $Y L$, Guo ZH: A study of HCV infection among part of the blood donors and recipients in Lanzhou. Journal of Lanzhou Medical College 1996, 2:63-64, [in Chinese].

235. Sheng XM, Wang J, Chen BZ: Report of anti-HCV detection in blood donors. Microbiology and Immunology 1996, 3:15-16, [in Chinese].

236. Du GJ, Wang YN, Liu XP, Cao MY: A preliminary investigation on HCV infection among voluntary blood donors in four districts of Gansu. Northwest National Defense Medical Journal 2002, 23:379, [in Chinese].

237. Pan C, Wang JX, Zhu Q, Li QG: A preliminary investigation on Hepatitis C virus among various liver diseases and blood donors in Fujian province. Fujian Medical Journal 1993, 3:51, [in Chinese].

238. Xu YC, Xu NF: A serological survey on hepatitis $C$ virus infection among blood donors in Gutian. Documentation and Information of Preventive Medicine 1998, 1:13, [in Chinese].

239. Ye C, Xu MS, Ma MZ: Analysis on serological anti-HCV detection among blood donors in Fuzhou. Fujian Medical Journal 1994, 3:107, [in Chinese].

240. Hu GD, Lin JH: A report on 62 cases of hepatitis $C$ virus infection in Putian City. International Medicine 1995, 6:164-165, [in Chinese].

241. Huang ZH, Wang GZ: Anti-HCV detection results in 178 blood donors analyzed. Journal of Qiannan National Medical College 1996, 9:11, [in Chinese].

242. Wang CY: Analysis of HBV and HCV infection among medical staff and non-medical personnel blood donors. Journal of Qiannan National Medical College 2001, 3:171, [in Chinese].

243. Jing BN, Ding JJ, Tian M, Bao LY, Jiang HG, Shen RG: Investigation on HCV infection among hematologic disorder patients after the implementation of anti-HCV screening. Guizhou Medicine 1998, 1:33-35, [in Chinese].

244. Dong JM, Zhang YD, Teng M, Li LC, Tang WK: Anti-HCV detection results in 3110 blood (plasma) donors analyzed. Guizhou Medicine 1996, 4:209-211, [in Chinese].

245. Xu CF, Jiang JN: Hpatitis virus infection and screening measures among blood donors in Carey ethnic region. Journal of Qiannan National Medical College 1999, 2:104, [in Chinese].

246. Gu Y, Li SQ: Hpatitis C virus infection in bood donors. Journal of Zunyi Medical College 1994, 3:244-245, [in Chinese].

247. Ding JJ, Qian JY: Investigation on serologic HCV antibody among sexual promiscuity in Guiyang. Journal of Epidemiology 1993, 14:231-233, [in Chinese].

248. Qiu SH, Lu R: Epidemiology of syphilis infection among blood donors in Guiyang. Modern Medicine and Sanitation 2004, 20:1698, [in Chinese].

249. Zhou DG, Jiang WL, Fang YR, Chen MD, Peng XZ: Investigation on serological hepatitis $C$ antibody among blood donors in Qiandongnan. Journal of Zunyi Medical College 1997, 20:28, [in Chinese].

250. Bai LJ, Li C, Bi T: 312 cases of blood donors detected by ELISA and RTPCR and a comparative study of anti-HCV and HCV RNA. Journal of Shenyang Medical College 1997, 1:48-49, [in Chinese].

251. Li HX: HCV infection among some people of Dandong in research. Modern Medicine and Sanitation 2006, 11:1751, [in Chinese].

252. Gu B, LV ZZ, Liu W, Liu YM, Chen YN, Wu TY, Han J, Cui CL, Zhou JZ, Wang Q, Zhen M, He ZQ: Investigation on hepatitis C virus infection among 469 blood donors in Dalian. Journal of Epidemiology 1994, 5:298, [in Chinese]

253. Li B, lin WC, Yang M: Serological anti-HCV, HBsAg, and anti-HIV detection reports among 1166 blood plasma) donors analyzed. Journal of Third Military Medical University 1995, 6:548-549, [in Chinese].

254. Hu J, Lin WC, Li B, Liu J, Chen Y, Peng J, Xia ZR: Detection results of antiHCV, anti-HIV, anti-TP and HBsAg of 42397 blood donors. Chongqing Medicine 2006, 12:1068-1069, [in Chinese].

255. Zhang $X Q$, Hu DR, Li MD: HBV and HCV infection in professional plasmapheresis dornors. Chongqing Medicine 1993, 3:196-198, [in Chinese].

256. Feng ZW: Survey on HCV antibody among voluntary blood donors in Yongchuan. Modern Medicine and Sanitation 2004, 20:268, [in Chinese].

257. Wu HY, Yang XH, Lu P: Anti-HCV detection results in 105 blood donors analyzed. Shanxi Medical Laboratory 1994, 9:29-31, [in Chinese].

258. Wang QH, Zhang HD: HBV and HCV infection in 294 blood donors with normal physical examination observed. Clinical Laboratory Science 1994, 12:96, [in Chinese]. 
259. Lei YF, Wang YQ, Xu HL, Yang C, Jiang WD, Li HH: A report of hepatitis $C$ virus infection in Hanzhong region. Shanxi Medical Journal 1994, 10:636-637, [in Chinese].

260. Yang SM, Yang ZL, Xie H, Hong BY: Hepatitis C virus infection and plasmapherdsis donors. Journal of Epidemiology 1994, 5:277, [in Chinese].

261. Li LL, Zhang XQ, Mu SJ, Li CY, Chen C: Coinfection of HGV with hepatitis $B$ virus and hepatitis $C$ virus of blood donors in Xi'an area. Journal of Fourth Military Medical University 2000, 2:146-147, [in Chinese].

262. Yao MJ, Li YN, Yang LY: Analysis of the results of blood screening unqualified and hepatitis epidemiology in unpaid blood donations in Xi'an city. Clinical Transfusion and Laboratory Medicine 2007, 1:25-27, [in Chinese].

263. Gao XH, Lu TS: 2000 detection results of blood donors. Qinghai Medical Journal 1997, 27:27, [in Chinese].

264. Qi Z: Anti-HCV detection among blood donors of Qinghai in research. Qinghai Medical Journal 1997, 11:34, [in Chinese].

265. Li XG: HBV and HCV infection detections among 864 Tibetans in Qinghai Province. Qinghai Medical Journal 2005, 2:59-60, [in Chinese].

266. Sun YQ, Zhang P, Zhang C, Wei GK, Dan M: Hepatitis C virus detection results among 16,769 cases of blood donors analyzed. Harbin Medicine 1995, 3:19-20, [in Chinese].

267. Yin SH, Sun DM, Xiao $Y$, Wang $Y X$ : A investigation on anti-HCV in professional blood donors. Chinese Primary Health Care 1999, 6:107-108, [in Chinese].

268. Di Z, Zhang SJ, Pan HW: HIV infection monitoring results among blood donors analyzed in Jiamusi City. Disease Surveillance 1998, 11:24, [in Chinese].

269. Bu SF, Qu M, Shi JL, Zhang YT: Survey of hepatitis C infection in Qiqihar. Practical Preventive Medicine 1998, 1:10-11, [in Chinese].

270. Yang DL, Zhao XP, Tang ZY, Li FH, Yu ZQ, Wang YK, Hao LJ: Investigation on transmission of HCV infection among different groups. Shanghai of Preventive Medicine 1995, 7:451-453, [in Chinese].

271. Zhen $H J$, Xing WG, Zhuang $H$, Zhao $B H$ : Viral hepatitis detection reports in more than 90 hospitals and blood banks all over the country. China Public Health 1995, 3:126, [in Chinese].

272. The Editorial board: Investigation on anti-HCV positive rate among blood donors in some districts of China. Transfusion Medicine 1994, 7:98-99, [in Chinese].

273. Han S, Shen X: A survey of hepatitis C virus antibody among blood donors and outpatients with liver disease in Shanghai. Journal of Infectious Diseases 1992, 10:37-38, [in Chinese].

274. Fu Y, Xia W, Wang Y, Tian L, Pybus OG, Lu L, Nelson K: The seroprevalence of hepatitis C virus (HCV) among 559,890 first-time volunteer blood donors in China reflects regional heterogeneity in HCV prevalence and changes in blood donor recruitment models. Transfusion 2010, 50:1505-11.

275. Dai ZC, Qi GM: Viral hepatitis in China: serological surveys (volume 1). Beijing: Science Press; 1997, 60-71, [in Chinese].

276. Jin SY, Wang XJ: Occult hepatitis C virus and post-transfusion hepatitis $C$ related. Liver 2008, 13:236-237, [in Chinese].

\section{Pre-publication history}

The pre-publication history for this paper can be accessed here: http://www.biomedcentral.com/1471-2334/11/88/prepub

\section{Submit your next manuscript to BioMed Central and take full advantage of:}

- Convenient online submission

- Thorough peer review

- No space constraints or color figure charges

- Immediate publication on acceptance

- Inclusion in PubMed, CAS, Scopus and Google Scholar

- Research which is freely available for redistribution

Submit your manuscript at www.biomedcentral.com/submit 